This item was submitted to Loughborough's Research Repository by the author.

Items in Figshare are protected by copyright, with all rights reserved, unless otherwise indicated.

\title{
Realising a resilient and sustainable built environment: towards a strategic agenda for the United Kingdom
}

PLEASE CITE THE PUBLISHED VERSION

http://dx.doi.org/10.1111/j.0361-3666.2007.01007.x

\section{PUBLISHER}

(c) The Author(s). Journal compilation (C) Overseas Development Institute. Published by Blackwell Publishing.

\section{VERSION}

AM (Accepted Manuscript)

\section{LICENCE}

CC BY-NC-ND 4.0

\section{REPOSITORY RECORD}

Bosher, Lee S., Patricia M. Carrillo, Andrew R.J. Dainty, Jacqueline Glass, and Andrew D.F. Price. 2019. "Realising a Resilient and Sustainable Built Environment: Towards a Strategic Agenda for the United Kingdom". figshare. https://hdl.handle.net/2134/4245. 
This item was submitted to Loughborough's Institutional Repository (https://dspace.lboro.ac.uk/) by the author and is made available under the following Creative Commons Licence conditions.

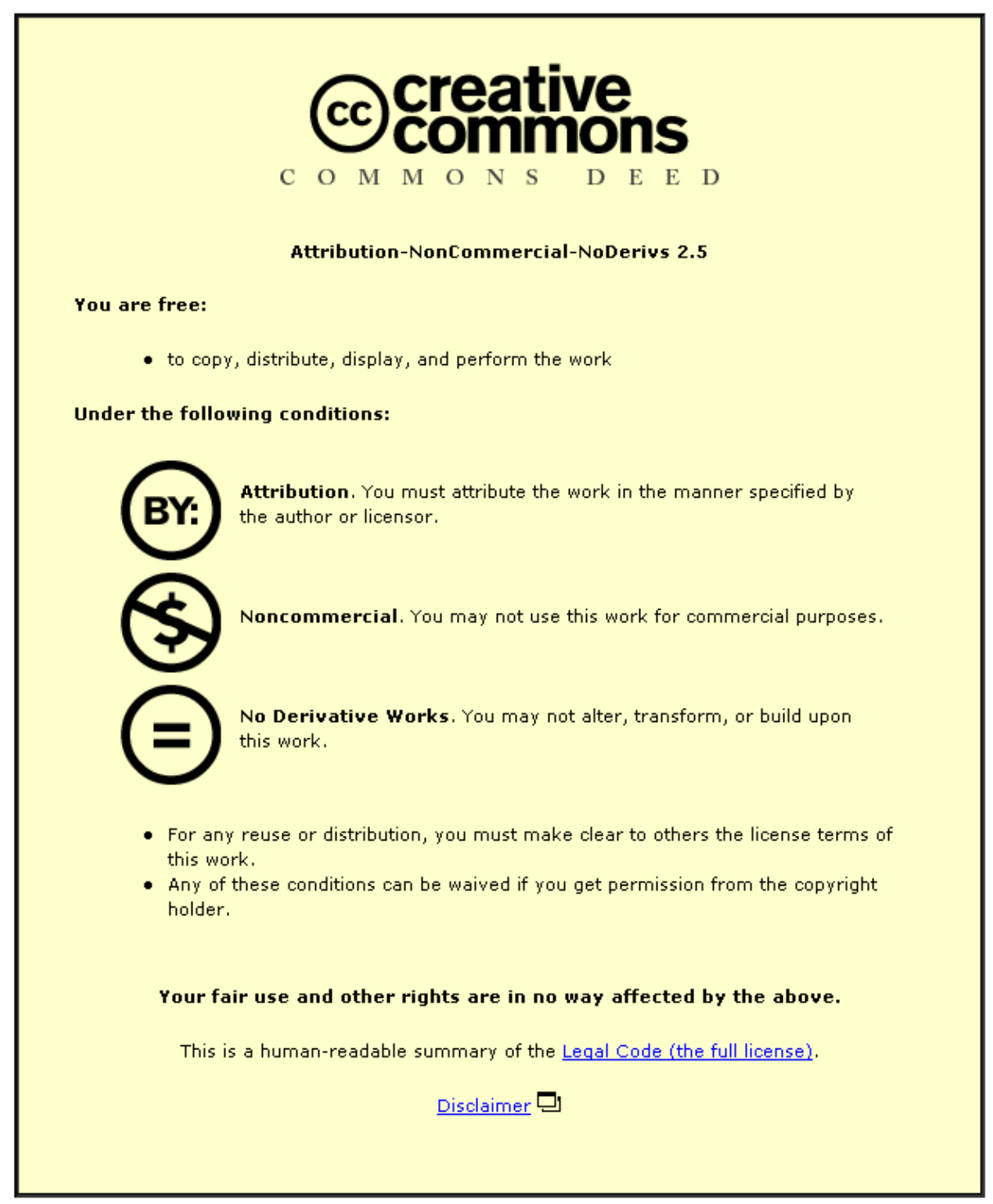

For the full text of this licence, please go to: http://creativecommons.org/licenses/by-nc-nd/2.5/ 


\title{
Realising a resilient and sustainable built environment: towards a strategic agenda for the United Kingdom
}

\author{
Lee Bosher, Patricia Carrillo, Andrew Dainty, Jacqueline Glass and Andrew Price ${ }^{\mathrm{i}}$
}

Recent natural and human-induced emergencies have highlighted the vulnerability of the built environment. Although most emergency events are not entirely unexpected, and the effects can be mitigated, emergency managers in the United Kingdom have not played a sufficiently proactive role in the mitigation of such events. If a resilient and sustainable built environment is to be achieved, emergency management should be more proactive and receive greater input from the stakeholders responsible for the planning, design, construction and operation of the built environment. This paper highlights the need for emergency management to take a more systematic approach to hazard mitigation by integrating more with professions from the construction sector. In particular, design changes may have to be considered, critical infrastructures must be protected, planning policies should be reviewed, and resilient and sustainable agendas adopted by all stakeholders.

Keywords: construction, critical infrastructure, emergency management, resilience

\section{Introduction}

Designing, constructing and operating resilient built assets demands an in-depth integrated understanding of how to avoid and mitigate the effects of emergencies and disasters in order to secure a resilient and sustainable future for the built environment.i ${ }^{\text {ii }}$ Resilience should be systematically built into the planning and design processes rather than added on as an afterthought. However, the extent to which this is being achieved - in the United Kingdom or elsewhere-is unclear.

In recent years some advances have been made to incorporate the roles of construction professionals into debates about climate change ${ }^{\mathrm{iii}}$ and sustainability ${ }^{\mathrm{iv}}$ However, integrating the construction professions into the processes associated with emergency management has been largely neglected (Spence and Kelman, 2004). Current and potential threats must be considered when planning, building and maintaining built assets and critical infrastructure. The concept of emergency management begins with the realisation that many emergencies are not unexpected but stem from:

The predictable result of interactions among three major systems: the physical environment, which includes hazardous events; the social and demographic characteristics of the communities that experience them; and the buildings, roads, bridges and other components of the constructed environment (Mileti, 1999, p. 3).

Although many emergency events are not entirely unexpected and can therefore be mitigated, emergency management does not currently play a sufficiently proactive role. Amid growing concern about the safety and security of the UK's civil infrastructure in relation to natural and human-induced threats, this paper explores the value of developing a more integrated and proactive multi-stakeholder approach to pre-emergency event planning and post-emergency event resolution.

\section{Emergency management}

Traditionally, emergency management has been motivated by immediate challenges or a response to single events (Schneider, 2002) while the profession has also been constrained by indifference or outright opposition to long-term planning. The United Nations adopted a concept of emergency management that combines activities in five phases: (a) pre-emergency preventive and mitigating actions; (b) formulation of emergency plans and preparedness activities; (c) emergency relief interventions; (d) short-term recovery and rehabilitation; and (e) longer-term reconstruction (UNOCHA, 1997). However, only the relief and recovery phases of emergency events receive much attention from the public or the media. Schneider (2002) states that emergency management is seen largely as a reactive profession because hazard mitigation is rarely regarded as urgent:

Policy makers and stakeholders alike tend to underestimate hazard potentials. They see a low probability of hazard occurrence, are reluctant to impose limitations on private property, often unwilling to bear the 
costs incurred by mitigation plans, and frequently are ambivalent toward hazard mitigation, because they see it as being in conflict with other values and goals (Schneider, 2002, p. 144).

Emergency management must be placed in a holistic setting and new initiatives should be taken to ensure that emergency management duties are seen as a shared responsibility that not only mitigates potential hazards, but also embraces the sustainability agenda (Trim, 2004). Sustainable development is 'development that meets the needs of the present without compromising the ability of future generations to meet their own needs' (WCED, 1987). Therefore, sustainable development is focused not merely on environmental management, but also on social and economic management-from household to international level. Emergency management should be concerned with people's capacity to manage their natural and built environment, and to take advantage of it in a manner that safeguards their, and their children's, futures (Walker, 1989). This shared responsibility can be achieved partly by integrating with construction industry professionals who possess knowledge and experience of how to design, build, retrofit and operate what are typically bespoke built assets.

\section{The British construction industry}

By and large, the built environment is designed, built and maintained by the construction industry, which can be defined as 'all those firms involved directly in the design and construction of buildings' (Morton, 2002, p. 39) and includes civil engineering and infrastructure work such as roads, bridges and railways. The British construction industry is worth some $£ 65$ billion a year, accounts for 8 per cent of gross domestic product, and employs some 1.9 million people (NAO, 2001). Construction is typically characterised as a predominately site-based process of creating structures out of constituent raw materials and components, perhaps including some office-based design work. Although these are important processes, the practice of construction depends on a complex network of relations between numerous organisations including contractors, suppliers, specialist sub-contractors and architects as well as a wide range of designers and engineers, factory-based fabricators and clients. One of the main problems encountered when investigating the construction industry and its associated technologies is how to map the fluid relations between all these players and intermediaries, each of which make their own distinctive input into the process of building (Moore and Dainty, 2004). Morton (2002) believes that typically professionals in the construction industry are fragmented from profession to profession. This fragmentation is exacerbated because some professionals are self-employed and/or subcontractors. Architects, surveyors and engineers are usually employed from outside construction firms as independent consultants and are liable to be disenfranchised from other professions (Morton, 2002, p. 97).

Relationships between the construction industry and government departments have often been characterised by conflict and mistrust, and this has contributed to poor performance (NAO, 2001). Morton (2002) believes that there are 10 points of contact between the government and the building industry, one of which is 'the state as facilitator'. In its role as a facilitator the government has gone some way towards integrating construction professions by bringing people together in the Strategic Forum for Construction—chaired by Sir John Egan (Morton, 2002). However, it is clear that, in addition to a need for construction industry professionals to integrate and establish the 'virtual company', it is also important to integrate the needs of clients into the agenda. ${ }^{v}$ While considering the needs of stakeholders, such as clients and end users, it is important to appreciate the extent to which they understand and embrace the agendas for a resilient and sustainable built environment.

The construction industry is not only a critical component of the nation's economy, it is also a fundamental factor in the quality of people's lives and the ability of the government to achieve many of its policy aims. However, the construction industry has not been sufficiently involved in preparedness planning and the mitigation of natural and human-induced hazards (Spence and Kelman, 2004). Construction industry disciplines should become more integrated not only within the industry, but also with other professions such as emergency managers. Perhaps the most significant area to which the construction industry could make a positive contribution to emergency management is the protection of critical infrastructures.

\section{Critical infrastructures}

Critical infrastructures are physical and cyber-based systems that are essential to the key operations of the economy and government. These systems are deemed so vital that their incapacity or destruction would have a debilitating effect on the defence, economic security and health of local or national administrations and 
populations. Types of critical infrastructure include: $(a)$ information and communications networks; (b) government services; (c) banking and finance; $(d)$ water supply; (e) electrical power, oil and gas production and storage; $(f)$ transport networks; $(g)$ emergency services; and $(h)$ public health services.

The focus of this paper is predominantly on the physical systems that are essential to the minimum operation of the economy and government, such as transport networks, emergency services, the energy and water supply and public health services. Traditionally, these physical systems have been designed, built and maintained by the myriad professions involved with the construction industry. If critical infrastructures are to be protected from natural and human-induced hazards, there is a pressing need for architects, urban planners, structural and civil engineers, materials suppliers, surveyors, contractors and clients to be made more aware of the importance of building resilient and sustainable infrastructures. This could be achieved by more effectively integrating the roles of construction industry professionals with emergency management activities in a way that builds on both sectors' existing knowledge and experience of the range of hazards that threaten the UK's built environment.

\section{Threats to the built environment}

Threats to the built environment in the UK are diverse and include extreme natural hazards, such as floods and storms, and human-induced hazards, such as terrorist attacks, explosions at industrial facilities and mass transportation accidents. Typically, these hazards cause minor disruption to the economy, infrastructure and residents of the UK but some commentators (e.g. UKCIP, 2002; Keane, 2005) believe that the magnitude and frequency of these extreme events are increasing. As such, current and potential future threats need to be considered when planning, building and maintaining the built environment.

\section{Fluvial and pluvial flooding}

Approximately 10,000 $\mathrm{km}^{2}$ (8 per cent of the total area) of land in England is at risk from fluvial flooding, including tidal rivers and estuaries (DTLR, 2001). An estimated five million people, two million homes and 185,000 businesses are at risk from flooding in England and Wales every year. The total value of exposed property, land and assets amounts to $£ 214$ billion (Crichton, 2005a). The risk of flooding in the UK has been amplified by changes to river hydrology caused by human activity, and partly by the increased development of areas at risk. Urban drainage is increasingly recognised as the 'Achilles heel' of flood management systems (UKCIP/EPSRC, 2003). This is because the run-off of rainfall in urban areas cannot follow a natural path and is usually constrained in completely artificial systems. The run-off problem is exacerbated by a combination of an ageing infrastructure and climate change. Changes in water usage over the lifetime of many older drainage systems already mean that they have little surplus capacity.

\section{Storms}

In much of the UK buildings are not currently designed to withstand storms of the severity experienced in other parts of Europe (LCCP, 2002). This is an issue that should be considered in more depth, particularly if the UK Government's Communities and Local Government (CLG) proposal to construct 'affordable houses' at a build cost of $£ 60,000$ becomes a reality. The level of damage varies according to building type, age and configuration. Spence et al. (1998) concludes that the older the building, the more vulnerable it is to wind damage. Conversely, Crichton (2005b) concludes that modern buildings in England and Wales are much more vulnerable to damage than older ones, mainly because older buildings were 'over engineered' while modern ones are built to building standards and codes that are not sufficiently in tune with resilience issues.

\section{Coastal erosion}

Approximately 30 per cent of the British coastline has been developed and some 2,500km² of land (1.5 percent of the total coastal area) is at risk of direct flooding from the sea (DEFRA, 2001). The direct impacts of coastal erosion can result in loss of life linked to storm surges and landslips, major capital losses through loss of coastal property, and disruption and damage to rail and road networks located near the coast, possibly necessitating protection or realignment at huge cost.

\section{Climate change}

According to UKCIP/EPSRC (2003), by the 2050s average annual temperatures are likely to have increased by between $1^{\circ} \mathrm{C}$ and $3^{\circ} \mathrm{C}$, accompanied by a likely shift to drier summers and wetter winters over much of the 
country. Other climate variables, such as solar radiation, wind, humidity and evaporation, will also be affected and undergo changes to their seasonal variations. Sea-level rises could provide an increasing challenge to developments located in coastal areas. Inevitably, such changes will have, and are already beginning to have, major consequences for the built environment, particularly critical infrastructures. The potential impacts of climate change on anthropogenic systems, of anthropogenic systems on natural systems, and their subsequent influences on natural and human-induced disasters are illustrated in figure 1.

Figure 1: Potential relationships between climate change and natural and human-induced hazards

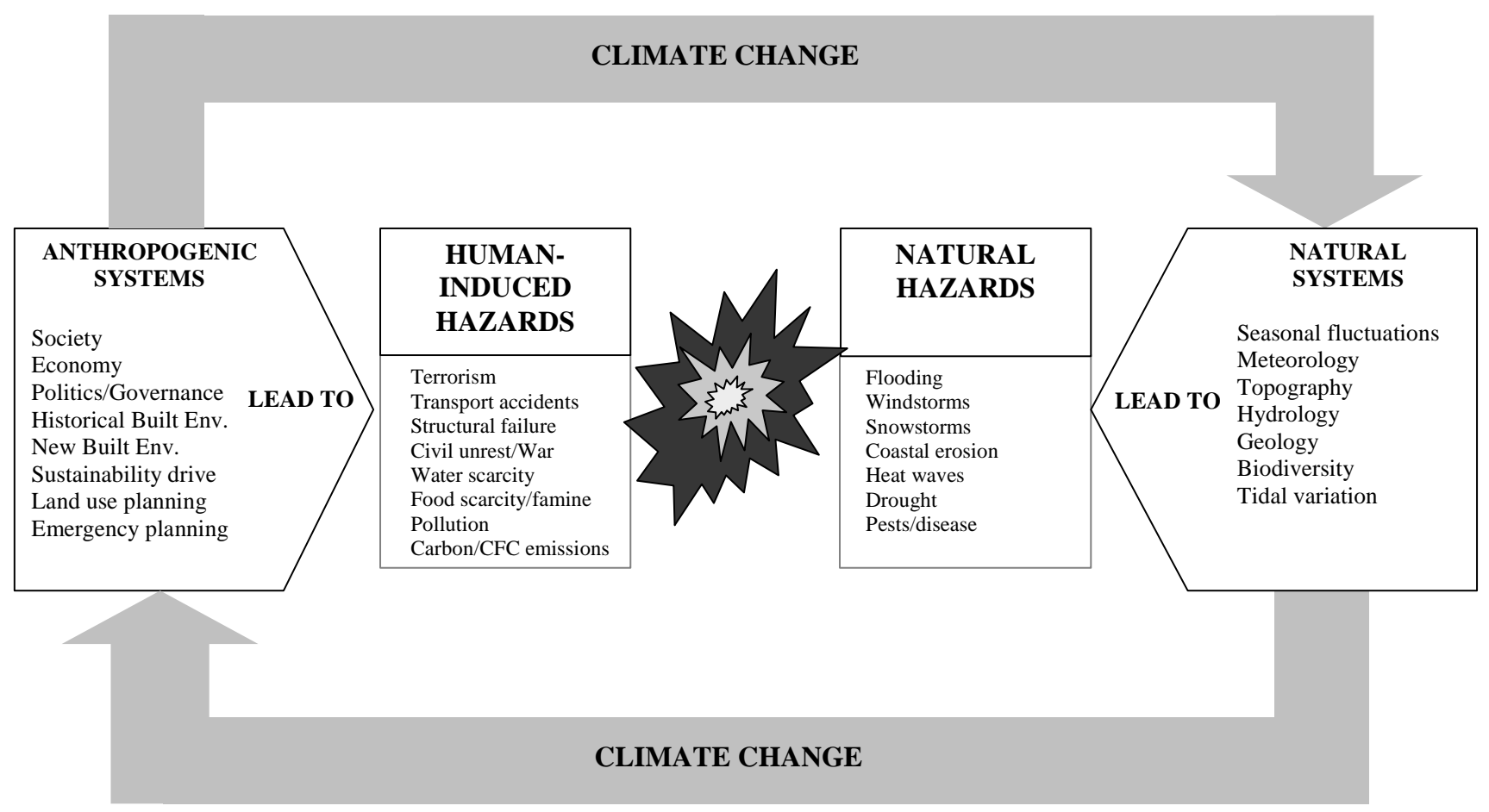

Ewins (1999) predicted in 1999 that the climate change prognosis to 2050 was: $1.5^{\circ} \mathrm{C}$ warmer; 8 per cent wetter than in 1961-90; sea levels $35 \mathrm{~cm}$ higher; wetter in northern Britain but drier in the south; gale frequencies to increase by up to 30 per cent; and increased probability that storm surges will exceed given thresholds. Salthouse (2002) states that the probability of hot summers in the southern part of the UK increases from 6 per cent in 1990 to between 56 per cent and 100 per cent in 2080. Palmer and Rälsänen (2002) reports the authors' probabilistic analysis of 19 global climate model simulations and concludes that winter precipitation in the UK could increase five-fold in the next 100 years. UKCIP (2002) predicts a possible increase in winter peak river flows of up to 20 per cent by 2050 because of climate change-the Association of British Insurers (ABI) suggests that this would approximately double flood risk (ABI, 2004).

Increasing urbanisation, in the form of urban expansion and densification, has resulted in a decline in the proportional cover of green space (EEA, 2002). This has increased pressure on the urban ecosystem, affecting surface temperatures, storm water run-off, carbon storage and biodiversity (Whitford et al., 2001; Pauleit and Duhme, 2000). Climate change and urban densification are partly dependent on lifestyle choices, but climatic changes may facilitate, inhibit or accentuate lifestyle choices. Therefore, the threats from events such as flooding, droughts, windstorms and heatwaves are likely to increase because of the pressures of climate change. The 'Stern Review' (Cabinet Office/H.M. Treasury, 2006) warns of a bleak future for the planet if societies and the built environment do not adapt to address the implications of a changing climate. The report (ibid) goes as far as to state that the benefits of strong and early action far outweigh the economic costs of inaction. The implications of any 'strong and early action' will pose important questions for the planning, design, construction and maintenance of the UK's built environment and the protection of critical infrastructures.

Consequently, when designing buildings, infrastructure and communities, it is important to plan for future climatic conditions throughout the design life of the development-and not just for the current climate. This should be seen as a commercial opportunity for professionals involved with the built environment. Welldesigned buildings, properly protected from the hazards associated with climate change, will be easier to sell 
or let and could also command higher prices. Opportunities are therefore available for organisations to position themselves as market leaders in the climate-related 'future-proofing' of buildings, thereby presenting a means of attracting new customers and gaining a competitive edge.

\section{Terrorist attacks}

In the context of attaining a resilient and sustainable built environment in the UK, one of the most high profile societal threats is that of terrorism. Moor (2002) notes that human settlements are designed to protect their inhabitants against attack by intelligent hostile elements. At the same time, the technology of war aims to counteract such defences. It is probable that socio-economic progress makes settlements more vulnerable because they become more reliant on increasingly extended supply lines and ever-expanding vital distribution networks of water, power, gas and telecommunications. Public social and security infrastructures such as health facilities, civil defence and the police also become particularly critical to survival. Moreover, globalisation increases the interconnectedness of major settlements to the extent that a disaster in one settlement can precipitate widespread disruption in many others. Increasingly, acts of terrorism are threatening communities worldwide (Keane, 2005) and in the past few years attacks have occurred on 'soft' (non-military) targets in Morocco, Spain, Turkey, the United Kingdom and the United States.

In addition to the list of critical infrastructures given above, the following should also be considered potential terrorist targets: (a) energy generation and distribution instillations; (b) petroleum and chemical infrastructures; $(c)$ economic institutions; $(d)$ water storage and distribution networks; $(e)$ critical government services; $(f)$ symbols of national achievement and culture; and $(g)$ large scale public events.

The implications of terrorist threats for the security and sustainability of the UK's infrastructure are difficult to quantify. However, while it is right to question whether it is 'possible to design a building to withstand an impact from a plane not yet invented in a scenario no one can imagine, not once, but twice, on a blue sky Tuesday morning' (Lakha and Moore, 2002, p. 81), further research into the design, construction and retrofitting of the built environment is obviously justified. For example, the planning of the 2012 Olympic Games in London in 2012 will have to embrace fully an agenda that mitigates the threats of terrorism and integrates the protection of critical infrastructures.

\section{Inappropriate planning}

Theoretically, the planning system attempts to allocate appropriate land for appropriate purposes while taking account of threats to that land, the use of adjoining land and the needs of the local population. Realistically, the role of the planning system-resolving contradictions and deep-rooted conflicts between competing private interests over the use and development of land, on the one hand, and public and community interests over property rights and development priorities, on the other-is an impossible one (Gillingwater and Ison, 2003, p. 561). Monbiot (2000) states that the planning system in the UK is biased in favour of developers to the detriment of local communities because only developers can appeal against local authorities' planning decisions. In contrast, in every other country in the European Union local people can use the planning system to object to planning decisions (Monbiot, 2000).

Competing pressures are demonstrated by the current situation regarding planning guidance and the need for more land in the UK to build more homes. Plank (2005) states that nearly 4 million new homes are needed in the UK over the next 15 years. Current government guidance, such as 'Planning Policy Guidance 3' (PPG 3, ODPM, 2000) aims to redevelop 'brownfield' sites before looking at 'greenfield' options. According to Planning Policy Guidance $25^{\mathrm{vi}}$ (PPG 25, DTLR, 2001), previously developed areas in locations at risk of flooding should be given preference over undeveloped or sparsely developed areas. The Barker report (2004) speculates about the limitations of an approach that prefers developing 'brownfield' sites over 'greenfield' sites in relation to housing development, and whether broader sustainability criteria should be applied to land use decisions. The ABI believes that the principle aim of PPG 25 should be to ensure that new development does not cause any net increase in flood risk for the area (ABI, 2004).

\section{The contribution of the construction industry}

Emergency management in the UK must become more proactive if a resilient and sustainable built environment is to be achieved and critical infrastructures are to be protected. One way in which emergency managers can become more proactive is by adopting an agenda that encourages the integration of professions from the construction industry. There is currently little commentary from emergency management, 
construction or civil defence-related literature on the contribution of the construction industry to the mitigation of natural and human-induced hazards. Nonetheless, it is fair to state that the construction industry has not been sufficiently involved with emergency management to date because:

1. Involvement in emergency management has largely been outside the remit and economics of construction activity, unless specific initiatives have been imposed by the government through legislation (Lorch, 2005). At the same time emergency managers have not been sufficiently proactive in making use of the knowledge and skills that construction professionals can offer.

2. The construction industry, in common with most industries, typically does what it needs to do in order to meet the required specifications, which are usually set by government legislation, while maximising profits.

3. The myriad professions involved with the construction process have found it difficult to integrate with each other, let alone with other professions outside the industry (DETR, 1998; Morton, 2002).

4. There has not been sufficient research spending in the industry on the strategies required to mitigate the threats discussed above (DTLR, 2002).

A summary of the built environment systems at risk from natural and human-induced hazards and the actions required to mitigate these hazards is provided in table 1. Professionals involved with the construction industry can make a significant contribution to many of the actions listed, such as making initial design changes and using retrofitting techniques to mitigate the effects of flooding, storms and climate change. Some of these actions are expanded on below.

Table 1 Summary of the built environment systems at risk from a range of hazards, their associated impacts and the actions required

\begin{tabular}{|c|c|c|}
\hline Built environment systems at risk: & Need to reduce impacts of: & Actions required: \\
\hline • Municipal buildings & - Flood risk to structures & - Consider design changes \\
\hline - Residential buildings & - Terrorist risk to structures & - Review land-use planning policy \\
\hline - Commercial/industrial buildings & - Poor conditions in internal environment & $\begin{array}{l}\text { - Integrate construction professions with } \\
\text { emergency planning }\end{array}$ \\
\hline - Transport infrastructure & - Subsidence and heave & $\begin{array}{l}\text { - Broach sustainability and the contradiction } \\
\text { between low cost and quality housing }\end{array}$ \\
\hline • Utilities infrastructure & • Slope instability & $\begin{array}{l}\text { - Research alternative options regarding } \\
\text { resilient materials and practices }\end{array}$ \\
\hline - Healthcare infrastructure & $\begin{array}{l}\text { - Damage to the structure and fabric of } \\
\text { buildings/infrastructure }\end{array}$ & $\begin{array}{l}\text { - Integrate emergency planning with urban } \\
\text { planning }\end{array}$ \\
\hline - Sustainable working practices & - Over burdened urban drainage systems & - Retrofit 'at risk' buildings and infrastructure \\
\hline • Insurance availability & • Inappropriate planning consent & - Learn from and adopt best practice \\
\hline • Heritage buildings/infrastructure & $\begin{array}{l}\text { - Poor practice and lack of integrated } \\
\text { approach }\end{array}$ & • Embrace the sustainability agenda \\
\hline - Availability of suitable land & & \\
\hline
\end{tabular}

\section{Innovation and knowledge}

The resilience agenda must be embraced by all stakeholders including government agencies, planners, architects, designers, structural and civil engineers, developers, suppliers of construction materials, building operators and last but not least the clients. Buildings and infrastructure should be designed to maximise their resilience to a range of hazards and to minimise damage to critical infrastructures such as transport and power supplies. The decisions taken now will determine the burdens that future generations inherit. Therefore, communities and industry must be equipped to address the root causes of disasters and to undertake the complex work of arriving at a negotiated consensus about which losses are acceptable, which are unacceptable, and what types of action they are willing to take (Mileti, 1999). To get anywhere near to achieving such a negotiated consensus, there is a need to improve the level of natural and human-induced risk 
and hazard awareness through the professional training and development of architects, planners, engineers, developers, and so on.

It has been proposed that incentives should be provided for proactive building design that mitigates for disaster events (including the potential effects of climate change) such as tax breaks for constructing buildings to disaster resistant standards (Keane, 2005). The construction sector should embrace and pre-empt regulatory changes regarding resilient and sustainable construction and use these as an opportunity for competition in the sector, nationally and globally, and as a 'reputation damage' avoidance measure.

The possible impacts of climate change should be considered when decisions are made about the location, materials used, processes and operational requirements of the present and future built environment. Expertise in the form of innovative design, materials and building techniques should be systematically incorporated into discussions about how to build and operate sustainable and resilient built assets, particularly critical infrastructures. For example, if buildings are to be constructed in flood risk areas, then why not build them from water resilient materials and with integral flood defence measures at ground level? Research agendas focused on the impact of climate change on the UK's built environment will have to continue and possibly be accelerated. Research must focus on the development of appropriate construction materials and processes and the possible impact of these on resilience and sustainability requirements.

\section{Operational elements}

The operational elements of emergency management are largely related to the planning, knowledge, skills and resources required to respond to an emergency situation or emergency events. There is evidence of the ways in which construction industry professionals helped police and the emergency services after the terrorist attacks in London on 7 July 2005 by providing equipment to assist the police with their search and rescue activities (Building, 2005). This example illustrates one role that construction professionals can play in responding to emergency events and highlights opportunities for construction consultancies to specialise in post-event response and rehabilitation activities. Other operational elements include the provision of clear and up-to-date information and schematics of buildings and infrastructure affected by emergency events, the development of a database of local and regional resources such as heavy plant and specialist tools that could be used in site clearance or search and rescue operations, and a register of trained and skilled personnel, such as building surveyors, structural engineers and demolition experts, who could assist with assessments of the effects of emergency events on structures.

\section{Planning}

The location of a development is largely defined by the availability of land and the desire of a developer and/or national or local authority to build residential, commercial, public or industrial assets. Some 27 per cent of new housing is located in flood hazard areas (Crichton, 2005b), and it is pertinent to consider why the government or a developer would want to build on such risky sites. vii Flooding is the most frequent and costly threat to homes in the UK. (DTLR, 2001) Climate change is likely to increase this problem (Crichton, 2005c). The planning of sustainable communities and critical infrastructures must take account of flood risk because the government's proposals could increase the national cost of flooding by $£ 55$ million per year (ABI, 2005). Consequently, it is important to educate developers_including government agencies-about the risk posed by flooding to proposed developments, rather than relying on a planning system that is too weak to fight the competing pressures that are highlighted in this paper. Much of this risk could be reduced through sensible planning, innovative design and improved local defences. Planning should be a key element of the activities of the government, emergency managers and the construction industry to secure the future of the UK's built environment because planning underpins decisions about what is built and where it is built.

\section{Legislation}

Vivian et al. (2005) states that few construction guidance documents, either in the UK or more broadly across Europe, indicate clearly that the potential impacts of climate change have been considered in their development—although some recently amended documents such as the Building Standards have taken climate change into consideration. The Eurocodes do not specifically discuss the impacts of climate change, but there is provision for regional variations in climatic conditions, such as wind or snow maps, to be taken into consideration in their application (Vivian et al., 2005). ${ }^{\text {viii }}$

If the $\mathrm{UK}$ is to attain a resilient and sustainable built environment the first priority must concern the location and design of future buildings and large-scale developments (Crichton, 2005c). These should be 
located in areas least vulnerable to severe weather and rises in sea levels, and the buildings should be designed to minimise their carbon emissions and vulnerability to the elements, or damage to infrastructure such as transport and power supplies. Consultation with insurers, combined with simple and low cost government measures, could bring a huge amount of expertise to the table in order to reduce problems in the future (Crichton, 2005a). Participation and partnerships must therefore be expanded to enable lessons to be learned from past experiences.

\section{Regulatory initiatives}

Spence (2004) argues that the regulatory side of managing risks from natural hazards, such as statutory building codes, works in some circumstances but tends to reduce risk unevenly. At the same time, such codes are difficult to apply consistently because of their complexity. Nevertheless, legislation is needed to support technical programmes, such as strengthening existing buildings against loads, while insurance schemes have the potential to contribute significantly to mitigation efforts. Initiatives from the construction industry could focus on policy amendments and technical innovations. According to Spence and Kelman, protecting buildings from the threat of natural hazards 'is often regarded as a relatively small part of the task of building sustainably, but it is an important part and that importance is growing' (Spence and Kelman, 2004, p. 365).

One way in which legislative changes, technical innovation and expanding partnerships could be integrated into the construction process could be through the use of Private Finance Initiatives (PFIs). PFIs have been widely criticised in some circles (see Monbiot, 2000) as an inefficient way for the government to finance public projects such as schools, hospitals and roads. However, the long-term costing involved with PFI projects could provide an opportunity for the private companies involved to forge partnerships in the industry and incorporate whole-life performance into the resilience of the structures that are to be built. Rather than building an asset and then moving off site with no regard to its future use and resilience, those organisations awarded PFI contracts have a vested interest in ensuring that the operational and maintenance costs of the built assets are minimised during the 20-30 years that they are responsible for the school, hospital, motorway, and so on. These possibilities can become policy if the government is proactive enough to combine PFI projects, particularly those that involve critical infrastructure, with long-term visions that encompass resilient and sustainable structures.

\section{The integration of professions}

The discussion above alludes to the multiplicity of disciplines involved in the construction industry that should be more involved in emergency management. Lorch (2005) believes that some of the nontechnological problems of emergency planning are a demonstration of the disciplinary boundaries in the scientific community and between the scientific community and the policy community. Consequently, there is a need for policy-makers, practitioners and the academic community to understand that hazard and risk reduction and emergency management should be more integrated than in the past. Hazard mitigation in urban planning is more than a niche issue in the construction industry and knowledge about disruptive events must be incorporated into the mainstream emergency-management process (Lorch, 2005). Involving constructionrelated stakeholders in Regional Resilience Teams and Forums could facilitate this integration.ix

Research communities will also need to be more integrated if the temporal concepts of life-cycle planning, and the impacts of hazards are to be better understood in the future. Lorch (2005) believes that higher education and training can play a major part in the integration of sustainable development, as well as hazard, vulnerability and risk reduction principles into the domain of built environment studies and asks, 'Should we be investigating the capabilities of the built environment under extreme circumstances as well as subtle, protracted circumstances?' (Lorch, 2005, p. 210). For example, in Europe a lot of work has been done to re-educate architects to design eco-friendly and more resilient buildings, which not only have lower carbon emissions, but are also more resistant to floods and storms (Roaf et al., 2005).

\section{Impediments to integration}

Multidisciplinary integration appears to be the 'holy grail' necessary to maximise the knowledge and skills required to achieve a resilient and sustainable built environment. Trim (2004) highlights a number of important considerations related to an integrated approach to emergency management and the differences between, and sometimes competing priorities of, those involved. For example, people involved with the fiscal elements of local authority administration may be reluctant to invest more than they feel necessary in 
mitigating the effects of extreme events that may never occur, especially if governmental funding for emergency planning is not 'ring fenced'. There are also key conflicts in the planning process between the requirements of the local authority, current residents, future residents and developers (see box 1, which is a simplification of a complex set of interactions).

The integration of construction and emergency management professionals requires the input of civil engineers, architects, town and transport planners, building surveyors, draughtspersons, building inspectors, quantity surveyors, materials suppliers, contractors, clients, government agencies, emergency planners, healthcare trusts, the emergency services and utilities companies, to name a few, as well the various institutions and organisations that represent the stakeholders discussed above. However, it is important to recognise that essential differences exist between professional people from different cultures (Pavlica and Thorpe, 1998).

\section{Box 1: An example of conflicting priorities}

Developers that want to build a residential housing estate in the leafy suburbs will typically prefer to develop a 'greenfield' site rather than a 'brownfield' site (that may need expensive remediation work and be located near 'unattractive' industrial units that may still be operational). This will inevitably put pressures on a planning system that, some have suggested, is weak and favours the desires of the developer over the local resident. Developers may also wish to use the cheapest and the least 'environmentally friendly' materials because competition from rival developers means they need to put short-term profits before long-term sustainability. The design of the homes may not embrace new designs and technologies because such innovations are perceived by the developer to be more expensive than traditional well-established approaches and the designs may not be what the client wants. The client also wants value for money-a situation exacerbated by the relatively high average house prices in the UK. The suburban or 'out of town' location of the housing estate will typically mean that the residents of the estate will rely more on private transport unless the local authority or private transport companies invest in extended public transport links. The problems associated with these scenarios are exacerbated when planning permission has been granted on land that is at risk of flooding.

Indeed, differences exist between the disparate professionals working in the area of emergency management (Trim, 2004) and construction (Morton, 2002) because an individual's identity is formed by history, tradition, politics and education and is further influenced by management learning and development. It is shaped also by factors associated with organisational change (Pavlica and Thorpe, 1998) and types and methods of employment (Morton, 2002). Bresnen et al. (2005) have explored the social capital in construction firms that derives from the network of social relationships in which people are embedded. They state that their case study findings lend weight to the argument that social capital is of benefit to organisations and an important potential source of value creation for firms. Innovative processes are facilitated by or even dependent on extended networks of social contacts, the creation of dialogues and shared meaning and the establishment of appropriate norms to govern interactions (Bresnen et al., 2005). However, on the negative side, shared systems of meaning can exclude alternative views or sources of knowledge from outside the community.

Table 2 provides a summary of some of the key threats as well as some examples of the actions that must be considered if the threats highlighted in this paper are to be mitigated. The actions outlined in table 2 illustrate the broad range of disciplines, public agencies and private companies that should become involved in mitigating the range of hazards that threaten the UK. Typically, the legislation-related actions must be undertaken by central government agencies-possibly influenced by lobby groups, trade associations and trade representatives. Planning changes must be driven by the government, particularly agencies such as the Environment Agency (EA), and the Department for Environment Food and Rural Affairs (Defra) and the ELG, while local authority planners should take innovative steps to mitigate hazards by addressing the weaknesses in the current planning guidelines to ensure that lessons are learned from the past. 
Table 2: A selection of key threats to the UK and the scope of actions required

\begin{tabular}{|c|c|c|c|c|}
\hline \multirow{2}{*}{$\begin{array}{l}\text { EXAMPLES } \\
\text { OF KEY } \\
\text { THREATS }\end{array}$} & \multicolumn{4}{|c|}{ KEY ACTIONS } \\
\hline & Legislation & Planning & Innovation [examples of] & Knowledge \\
\hline Generic & $\begin{array}{l}\text { Regulatory requirements for the off-site } \\
\text { retention of documents related to the } \\
\text { design, construction, operation, } \\
\text { maintenance and modification of buildings } \\
\text { Overhaul insurance strategies and schemes } \\
\text { to promote both mitigation and adaptation. } \\
\text { Provide financial incentives to companies } \\
\text { that embrace the resilient and sustainable } \\
\text { construction agendas }\end{array}$ & $\begin{array}{l}\text { Integrate emergency planning and urban planning } \\
\text { Integrate construction professions with the urban } \\
\text { and emergency planning processes } \\
\text { New developments that are inappropriately } \\
\text { located without sufficient mitigation measures } \\
\text { should be refused insurance cover or have very } \\
\text { large flood excesses applied to them. }\end{array}$ & $\begin{array}{l}\text { Establish a database to enable the provision of accurate } \\
\text { and up-to-date information/schematics to emergency } \\
\text { responders } \\
\text { Use PFI projects as exemplars for resilient and sustainable } \\
\text { whole life costing initiatives } \\
\text { Consider role of construction professions and equipment } \\
\text { in emergency planning and response activities } \\
\text { The construction sector should embrace and pre-empt } \\
\text { regulatory changes regarding resilient and sustainable } \\
\text { construction and use them as an opportunity for } \\
\text { competition within the sector, nationally and globally and } \\
\text { as a 'reputation damage' avoidance measure }\end{array}$ & $\begin{array}{l}\text { Integrate risk and hazard awareness training into } \\
\text { the professional training of architects, planners, } \\
\text { engineers, developers, etc } \\
\text { Encourage innovation and competitiveness } \\
\text { Clients and consumers should be made aware of the } \\
\text { benefits of resilient and sustainable built assets in } \\
\text { contrast to the 'lowest price' options }\end{array}$ \\
\hline Floods & $\begin{array}{l}\text { Strategic Risk Assessments should be } \\
\text { required for Regional Spatial Strategies } \\
\text { and Local Development Documents in } \\
\text { hazard risk locations } \\
\text { Incorporate flood resilience measures into } \\
\text { building design codes } \\
\text { The PPG } 25 \text { sequential test should be } \\
\text { strengthened to take explicit account of } \\
\text { climate change in flood planning zones }\end{array}$ & $\begin{array}{l}\text { The Environment Agency (EA) should be made a } \\
\text { statutory consultee for all new developments } \\
\text { (including redevelopments) in flood risk locations, } \\
\text { accompanied by a transparent reporting process } \\
\text { Local Authorities should carefully consider } \\
\text { planning applications for developments in flood } \\
\text { risk locations, and only grant planning } \\
\text { permissions once satisfied that all the major } \\
\text { sources of flooding have been adequately } \\
\text { mitigated }\end{array}$ & $\begin{array}{l}\text { Developers should carry out detailed Flood Risk } \\
\text { Assessments to inform the master-planning and design of } \\
\text { new developments or redevelopments with flood issues } \\
\text { Restricting the ground-floor space to flood-compatible } \\
\text { uses, e.g. car-parking and increased usage of SuDS } \\
\text { Raising the ground floor above the likely flood level. } \\
\text { Buildings with their own integral flood defence measures } \\
\text { such as door flood guards and airbrick covers }\end{array}$ & $\begin{array}{l}\text { The impacts of increased precipitation on hard } \\
\text { surface run-off and stresses on the drainage system } \\
\text { need to be considered } \\
\text { All stakeholders need to understand when and why } \\
\text { a decision has gone against an EA objection } \\
\text { Research alternative options regarding flood } \\
\text { resistant materials and designs } \\
\text { Educate the public about flood protection options } \\
\text { for individual properties. }\end{array}$ \\
\hline Storms & $\begin{array}{l}\text { Incorporate storm resilience measures into } \\
\text { building design codes }\end{array}$ & $\begin{array}{l}\text { Developments based in storm risk areas could be } \\
\text { encouraged to plant natural wind breaks such as } \\
\text { trees }\end{array}$ & $\begin{array}{l}\text { Consider innovative design changes to structures built in } \\
\text { zones prone to storm events, such as increased load } \\
\text { requirements for roofs and external cladding }\end{array}$ & $\begin{array}{l}\text { Structural engineers need to review resilient } \\
\text { construction and design requirements for roofs and } \\
\text { cladding }\end{array}$ \\
\hline $\begin{array}{l}\text { Coastal } \\
\text { erosion }\end{array}$ & $\begin{array}{l}\text { Extra defences will be required for the } \\
\text { channel ports and extra protection required } \\
\text { for nuclear power stations located on the } \\
\text { coast }\end{array}$ & $\begin{array}{l}\text { The EA should be made a statutory consultee for } \\
\text { all new developments (including redevelopments) } \\
\text { in locations at risk from coastal erosion, } \\
\text { accompanied by a transparent reporting process }\end{array}$ & $\begin{array}{l}\text { The adaptation strategies required to mitigate the effects of } \\
\text { coastal erosion are likely to be similar to those required for } \\
\text { flood and storm risks }\end{array}$ & $\begin{array}{l}\text { Structural engineers need to review resilient } \\
\text { construction and design requirements for sea } \\
\text { defences, building facades, roofs and external } \\
\text { cladding }\end{array}$ \\
\hline $\begin{array}{l}\text { Climate } \\
\text { change }\end{array}$ & $\begin{array}{l}\text { Legislation required to drive the resilience } \\
\text { agenda } \\
\text { Legislation is needed to support technical } \\
\text { programmes, such as strengthening } \\
\text { existing buildings against loads }\end{array}$ & $\begin{array}{l}\text { The EA should be made a statutory consultee for } \\
\text { all new developments (including redevelopments) } \\
\text { in locations at risk from coastal erosion, floods } \\
\text { and storms, accompanied by a transparent } \\
\text { reporting process }\end{array}$ & $\begin{array}{l}\text { Materials used for fixtures and fittings will have to be } \\
\text { tested to assess their resilience to a wide range of potential } \\
\text { hazards } \\
\text { Increase insulation levels to reduce artificial heating and } \\
\text { cooling costs } \\
\text { Maximise profits by reducing on-site wastage }\end{array}$ & $\begin{array}{l}\text { Research alternative options for resilient materials, } \\
\text { designs and practices } \\
\text { Use Foresight Panels and processes to deliver } \\
\text { future strategic options and recommendations }\end{array}$ \\
\hline
\end{tabular}

Note: Terrorism has not been included in this table because most of the legislative, planning, innovation and knowledge issues are likely to be building, service or site specific 


\section{Conclusions}

Recent natural and human-induced events have highlighted the fragility of the built environment and its vulnerability to disasters and emergencies. At particular risk are critical infrastructures that are essential to the operation of the economy and government such as transportation networks, the emergency services, energy and water supplies and public health services.. These physical systems have traditionally been designed, built and maintained by the many types of profession involved in the construction industry. However, the construction industry has not been sufficiently involved in planning to mitigate the effects of natural and human-induced hazards (Spence and Kelman, 2004).

If a resilient and sustainable built environment in the UK is to be achieved, emergency management must become more proactive and more integrated with other professions. One way in which this can be achieved is by adopting an agenda that encourages the integration of professions from the construction industry by, for example:

- Involving construction-related stakeholders in Regional Resilience Teams and other regional forums, thereby facilitating the integration of the skills that construction disciplines can offer. Emergency management and construction professions could then become more involved with locational planning, as well as developing building codes and design codes related to future developments in hazard and risk areas. This is of particular importance to the protection of critical infrastructures.

- The construction sector should embrace and pre-empt regulatory changes regarding resilient and sustainable construction and use them as an opportunity to compete in the sector nationally and globally and as a 'reputation damage' avoidance measure. In this way the construction industry can make a significant contribution to mitigation initiatives while seeing the required innovations as opportunities to become leaders in the fields of resilient structures, sustainable construction, and so on.

- Construction professionals, such as structural and civil engineers, architects and designers, could offer innovative retrofitting solutions to existing developments in hazard prone areas.

- All stakeholders should adopt resilient and sustainable agendas. Risk and hazard awareness training should be systematically integrated into the professional training and professional development of architects, planners, engineers, developers, and so on. Cross-disciplinary training for construction professionals and emergency managers should be encouraged. At the same time clients and consumers should be made aware of the benefits of resilient and sustainable built assets as opposed to the 'lowest price' options.

- Research must be expanded to include assessments of the resilience of materials, fixtures and fittings to a wide range of potential hazards. Studies should also be conducted to find options for resilient and sustainable materials, designs and processes.

Emergency management needs to be more proactive than it is currently and to embrace a strategic agenda that integrates a wide range of professions from the construction sector. Emergency management that does not integrate the range of experience and skills that the construction industry has to offer is tantamount to gross mismanagement of the built environment and should be viewed as 'unsustainable development'.

\section{Correspondence}

Lee Bosher. Department of Civil and Building Engineering, Loughborough University, Leicestershire, England LE11 3TU; e-mail L.Bosher@lboro.ac.uk.

\section{References}

ABI (2005) Safe as Houses? Flood Risk and Sustainable Communities. April 2005. Association of British Insurers, London.

ABI (2004) Review of Planning Policy Guidance Note 25: Development and Flood Risk. Consultation response. October 2004. Association of British Insurers, London.

Barker, K. (2004) Review of Housing Supply: Delivering Stability, Securing our Future Housing Needs. Office of the Deputy Prime Minister. HMSO, London. 
Bennett, J., and S. Jayes (1998) The Seven Pillars of Partnering: A Guide to Second Generation Partnering. Thomas Telford, London.

BRE (2000) Potential Implications of Climate Change in the Built Environment. Building Research Establishment, Garston.

Bresnen, M., L. Edelman, S. Newell, H. Scarbrough and J. Swan (2005) 'Exploring social capital in the construction firm’. Building Research and Information. 33 (3). pp. 235-244.

Building (2005) 'Aftermath of terrorist bombs'. Building. 15 July 2005. pp. 10-11.

Cabinet Office/HM Treasury (2006) Stern Review on the Economics of Climate Change. Cabinet Office/Her Majesty's Treasury, London.

CIB (1999) Agenda 21 on Sustainable Construction. Publication 237. International Council for Research and Innovation in Building and Construction (CIB), Rotterdam.

Crichton, D. (2005a) 'About floods'. Accessed from the Benfield Hazard Research Centre website (4 August 2005), http://www.benfieldhrc.org/floods/index.htm.

Crichton, D. (2005b) 'Toward an integrated approach to managing flood damage'. Building Research and Information. 33 (3). pp. 293-299.

Crichton, D. (2005c) 'Insurance and climate change'. Paper presented at the Conference on Climate Change, Extreme Events and Coastal Cities: Houston and London. 9 February. Houston, Texas.

DEFRA (2001) National Appraisal of Assets at Risk from Flooding and Coastal Erosion, including the Potential Impacts of Climate Change. Department for Environment, Food and Rural Affairs, London.

DETR (1998) Rethinking Construction. HMSO, London.

Department of Trade and Industry (2004) Better buildings: Better Lives, Sustainable Buildings Taskforce Report. May 2004. Department of Trade and Industry, London.

DTLR (2001) Planning Policy Guidance 25: Development and Flood Risk. December 2001, Department for Transport, Local Government and the Regions, HMSO, London.

EEA (2002) 'Towards an urban atlas: assessment of spatial data on 25 European cities and urban areas'. Environmental Issue Report. 30. European Environment Agency, Copenhagen.

Ewins, P. (1999) The Truth About Global Warming. Royal Academy of Engineering, London.

Fairclough, J. (2002) Rethinking Construction Innovation and Research. DTI/DLTR, London.

Gillingwater D. and S. Ison (2003) 'Planning for sustainable environmental futures'. D. A. Hensher and K. J. Button (eds) (2003) Handbook of Transport and the Environment. Elsevier, Oxford.

Givoni, B. (1998) Climate Considerations for Building and Urban Design. Van Nostrand Reinhold, New York.

Graves, H. M. and M. C. Phillipson (2000) Potential Implications of Climate Change in the Built Environment. Foundation for the Built Environment Report no. 2. December, Building Research Establishment, Garston.

Hay, G. and S. Richardson (2005) 'New Orleans: Lessons for the UK’. Building. 9 September 2005.

Keane, B. (2005) 'Major incident and disaster management'. The Structural Engineer. 7 June. 83 (11). pp. $22-$ 25.

Lakha, R. and T. Moore (eds) (2002) Tolley's Handbook of Disaster and Emergency Management: Principles and Practice. LexisNexis, Croydon.

Lancaster J. W., M. Preene and C. T. Marshall (2004) Development and Flood Risk: Guidance for the Construction Industry. CIRIA, London.

Lorch, R. (2005) 'What lessons must be learned from the tsunami?', Building Research and Information. 33 (3). pp. 209-211.

Mileti, D. M. (1999) Disasters by Design: A Reassessment of Natural Hazards in the United States. Joseph Henry Press, Washington, DC.

Milford, I. (2005) 'Climate change: a challenge for structural engineers'. The Structural Engineer. 7 June. 83 (11). pp. 26-27.

Monbiot, G. (2000) Captive State: The Corporate Takeover of Britain. Macmillan, London.

Moor, J. (2002) 'Cities at risk'. Habitat Debate. 7 (4). pp. 1-5.

Moore, D. R. and A. R. J. Dainty (2000) 'Work-group communication problems within UK design and build projects: an investigative framework'. Journal of Construction Procurement. 6 (1). pp. 44-55.

Morton, R. (2002) Construction UK: Introduction to the Industry. Blackwell Publishing, Oxford.

NAO (2001) Modernising Construction. National Audit Office, London.

ODPM (2003) Sustainable Communities: Building for the Future. February 2003. Office of the Deputy Prime Minister, London. 
ODPM (2000) Planning Policy Guidance 3: Housing, March 2000. Office of the Deputy Prime Minister, London.

Palmer, T. N. and J. Rälsänen (2002) 'Quantifying the risk of extreme seasonal precipitation events in a changing climate’. Nature. 415. pp. 512-514.

Pauleit, S. and Duhme, F. (2000) 'Assessing the environmental performance of land cover types for urban planning'. Landscape and Urban Planning. 52. pp. 1-20.

Pavlica, K. and Thorpe, R. (1998) 'Managers' perceptions of their identity: a comparative study between the Czech Republic and Britain’. British Journal of Management. 9 (2). pp. 133-49.

Plank, R. (2005) 'Sustainable building construction for structural engineers'. The Structural Engineer. 7 June. 83 (11). pp. 30-33.

Roaf, S., D. Crichton and F. Nicol (2005) Adapting Buildings and Cities for Climate Change. Architectural Press and Elsevier Press, London.

Salthouse, R. (2002) 'Lessons to be learned from the autumn 2000 floods disaster in the UK'. Insurance Research and Practices. 17 (1).

Schneider R. O. (2002) Hazard mitigation and sustainable community development. Disaster Prevention and Management. 11 (2). pp. 141-47.

Spence R. (2004) 'Risk and regulation: can improved government action reduce the impacts of natural disasters?'. Building Research and Information. 32 (5). pp. 391-402.

Spence R. and I. Kelman (2004) 'Editorial: Managing the risks from natural hazards'. Building Research \& Information. 32 (5). pp. 364-67.

Spence, R. J. S., W. H. Fawcett and A. J. Brown (1998) 'The windstorm vulnerability of the UK building stock'. Proceedings of the 4th UK Conference on Wind Engineering, Bristol.

Stunnell, A. (2004) Sustainable and Secure Buildings Bill 2004. HMSO, London.

Trim, P. (2004) 'An integrated approach to disaster management and planning'. Disaster Prevention and Management. 13 (3). pp. 218-225.

UKCIP (2002) Climate Change Scenarios for the United Kingdom. UK Climate Impacts Programme. April 2002. Swindon.

UKCIP/EPSRC (2003) Building Knowledge for a Changing Climate: The Impacts of Climate Change on the Built Environment, a Research Agenda. UK Climate Impacts Programme (UKCIP)/Engineering and Physical Sciences Research Council (EPSRC), Swindon / Oxford.

UNOCHA (1997) Humanitarian Report 1997: The Reduction of Natural, Technological and Environmental Disasters. United Nations Office for the Coordination of Humanitarian Affairs, Geneva.

Vivian, S., N. Williams and W. Rogers (2005) Climate Change Risks to Building: An Introduction. CIRIA, London.

Walker, P. (1989) Famine Early Warning Systems. Earthscan Publications Ltd, London.

WCED (World Commission on Environment and Development) (1987) Our Common Future [The Brundtland Commission]. Oxford University Press, Oxford.

Whitford, V., A. R. Ennos and J. F. Handley (2001) 'City form and natural process: indicators for the ecological performance of urban areas and their application to Merseyside, UK'. Landscape and Urban Planning. 57. pp. 91-103.

\section{Endnotes}

${ }^{i}$ Lee Bosher is a Research Fellow, Patricia Carrillo is Professor of Strategic Management in Construction, Andrew Dainty is Professor of Construction Sociology, Jacqueline Glass is a Lecturer in Architectural Engineering and Andrew Price is Professor of Project Management. All authors work in the Department of Civil and Building Engineering, Loughborough University, England, UK.

ii 'Resilient built assets' are those that have been designed, located, built, operated and maintained in a way that maximises the use of sustainable materials and processes while at the same time maximising the ability of the built asset to withstand the impacts of extreme natural and human-induced hazards.

iii Studies such as BRE, 2000; DEFRA, 2001; Givoni, 1998; Graves and Phillipson, 2000; Lancaster et al., 2004; Milford, 2005; Roaf et al., 2005; UKCIP/EPSRC, 2003; and Vivian et al., 2005 have integrated climate change issues and built environment issues.

iv Studies such as CIB, 1999; DTI, 2004; ODPM, 2003; Plank, 2005; Schneider, 2002; and Stunnell, 2004 have integrated sustainability and built environment issues. 
${ }^{v}$ Morton (2002, p. 17) makes the interesting observation that there has, in the past few decades, been a shift in the boundaries between public and private clients-especially where 'old public clients', such as the public utilities; public housing providers; central government agencies, such as the Highways Agency; nationalised industries, for example British Steel; and universities and other education institutions have become private clients.

${ }^{\mathrm{vi}}$ Please note that this paper was accepted for publication prior to the publication of Planning Policy Statement 25 (PPS25) in December 2006, although it should also be noted that many of the concerns raised in this paper related to PPG are still applicable to PPS25.

vii For example, Sebastian Catovsky, head of the ABI's natural perils department, believes that the Thames Gateway development in Greater London is highly susceptible to flooding. He argues that ' 91 per cent of the new housing in East London would be in the flood plain. In north Kent, 65 per cent is in the flood plains, in Kent Thameside 45 per cent and in Essex 35 per cent' (quoted in Hay and Richardson, 2005).

${ }^{v i i i}$ The Eurocodes are a set of common European structural design codes for civil engineering work. It is intended that, after a period of co-existence, they will eventually replace the national codes published by national standard bodies.

ix Government Offices, through the work of the Regional Resilience Teams, have an important role to play in the promotion and implementation of the regional tier of emergency management as set out in the 2004 Civil Contingencies Act. Regional Resilience Forums have been formed to bring together the key players in each region, such as local authorities, central government agencies, the armed forces and the emergency services. 